\title{
Likya Yolu'nu Yürüyen Turistlerin Seyahat Motivasyonları ve Memnuniyet Düzeyleri
}

\author{
Yılmaz AKGÜNDÜZ* Gaye KIZILCALIOĞLU**
}

\begin{abstract}
$\ddot{O} Z$
Bu çalışma ile Likya Yolu'nu yürüyen turistlerin demografik özellikleri, seyahat motivasyonlarl, genel memnuniyet düzeyleri ve geleceğe yönelik davranışsal niyetlerinin belirlenmesi amaçlanmıştır. Araştırma kapsamında veriler, kolayda örneklemi yöntemi tercih edilerek Mart-Nisan 2014 döneminde Likya Yolu'nu yürüyen turistlerden anket formu aractlığıyla toplanmıștır. Söz konusu anket formu turistlerin seyahat motivasyonlarını, memnuniyet düzeylerini ve demografik özelliklerini belirlemeye yönelik ifadelerin yer aldığ üç bölüm olarak tasarlanmıştır. Alan araştırması sonunda 407 geçerli ankete ulaşılmıştır. Hipotezleri test etmek için yapılan korelasyon ve regresyon analizleri sonucunda; Likya Yolu'nu yürüyen turistlerin seyahat motivasyonlarının sosyalleşme ve kendini gerçekleştirme, bağımsız seyahat etme, dünyayı tanıma, deneyim arayışı ve sakinlik araylşı olarak incelenebileceği tespit edilmiştir. Ayrıca sosyalleşme ve kendini gerçekleştirme motivasyonunun turistlerin genel memnuniyet düzeyini pozitif olarak etkilediği; genel memnuniyet düzeyinin ise turistlerin tekrar ziyaret etme ve tavsiye etme niyeti üzerinde negatif bir etkiye sahip olduğu belirlenmiștir.
\end{abstract}

Anahtar Kelimeler: Likya Yolu, Seyahat Motivasyonu, Turist Memnuniyeti, Destinasyon Sadakati.

JEL Sinıflandirması: M10, L83.

\section{Travel Motivations and the Satisfaction Levels of the Tourists Walking the Lycian Way}

\begin{abstract}
This study aims to determine the demographics, travel motivations, general satisfaction levels and future behavioral intentions of the tourists walking The Lycian Way. The data collected in the scope of the study were obtained from the tourists who walked in The Lycian Way in the MarchApril 2014 period by using the convenience sampling method with the questionnaires. The questionnaires were designed to determine the travel motivations, satisfaction levels and demographic characteristics of the tourists in three parts each of which containing expressions to define the abovementioned properties. At the end of the field study, 407 valid questionnaires were attained. As a result of the correlation and regression analyses; performed to test the hypothesis, it has been determined that the travel motivations of the tourists walking in The Lycian Way could be examined under the titles such as socializing and self-realization, traveling independently, knowing the world, searching for experience and quietness. It has also been determined that socializing and self-realization motivation affects the general satisfaction level positively. It has been observed that the general satisfaction level has a negative effect on the intention of revisiting the same place and on the intention of recommending it to other people.
\end{abstract}

Key Words: The Lycian Way, Travel Motivation, Tourist Satisfaction, Destination Loyalty

JEL Classification: M10, L83.

\footnotetext{
${ }^{*}$ Doç. Dr., Dokuz Eylül Üniversitesi, Seferihisar Fevziye Hepkon UBY, Gastronomi ve Mutfak Sanatları Bölümü, yilmazakgunduz@ hotmail.com

**Bilim Uzmanı, gayepazar@hotmail.com
} 


\section{GíRIŞ}

Turizm rotaları son yıllarda gelişme gösteren turizm trendleri arasında yer almaktadır (Meyer, 2004). Turizm rotaları turistik ürün geliştirmeye katkıda bulunmakla birlikte aynı zamanda yeni deneyimler kazanmak isteyen ziyaretçileri kendisine çekmektedirler. Gelişmekte olan turizm trendleri, standartlaşmış kitle turizminden uzaklaşarak daha bireysel, daha esnek ve daha anlamlı deneyim sağlayan alternatiflerin önem kazanmasına neden olmuştur (Hummelbrunner ve Miglbauer, 1994).

Her zaman yapılan aktivitelerin dışında bir deneyim yaşama arzusu içinde olan turistlerin turizm ürününden beklentileri; kültür ve bilgi düzeyini arttırması, eğlenceli ve kaliteli bir boş zaman değerlendirmesi yönünde olmaktadır (Božić ve Berić, 2013). Likya Yolu bu anlamda, beklentilerin hepsine cevap verebilen alternatif bir turistik üründür. Likya Yolu, 1996 yılında Garanti Bankası'nın kültür ve sanata destek projeleri yarışmasında, Kate Clow'un Likya Yolu adlı projesinin birinci seçilmesiyle günümüze kazandırılmıştır. Clow ve gönüller tarafindan işaretlenip haritalanan yol 1999 yılında hizmete açılmıştır. Üç bin yıllık tarihi bir ticaret yolu olan Likya Yolu, Fethiye Ölüdeniz'den Antalya'ya kadar uzanmaktadır. Tarih ve doğanın iç içe geçtiği Likya Yolu'nun uzunluğu 509 kilometredir ve 23 etaptan oluşmaktadır (Turgut ve Clow, 2010).

$\mathrm{Bu}$ araştırma Likya Yolu'nu yürüyen turistlerin demografik özelliklerini, seyahat motivasyonlarını, genel memnuniyet düzeylerini ve gelecekteki davranışsal niyetlerini belirlemek amacıyla tasarlanmıştır. Bu kapsamda öncelikle turistlerin seyahat motivasyonları ve memnuniyet düzeyleri konularının kuramsal çerçevesi oluşturulmaya çalışılmıştır. Çalışmanın araştırma bölümünde ise Likya Yolu'nu yürüyen turistlerden toplanan veriler analiz edilmiştir. Son olarak analiz sonuçları değerlendirilmiş ve önerilerde bulunulmuştur.

\section{KURAMSAL ÇERÇEVE}

\section{A. Turistlerin Seyahat Motivasyonları}

Turizm alanyazında turist davranışlarını açıklayan çok sayıda motivasyon teorisi ve yaklaşımı yer almaktadır (Kasim vd., 2013). Örneğin, McIntosh ve arkadaşları (1995), Maslow'un İhtiyaçlar Hiyerarşisindeki ihtiyaçları, seyahat gereksinimlerine uyarlayarak seyahat motivasyonlarını fiziksel, duygusal, kültürel, kişilerarası ve statü/prestij olarak açıklamaya çalışmışlardır. Kabul gören bir diğer teori, itme ve çekme faktörleri teorisidir (Damijanic ve Sergo, 2013). Dann'e (1977) göre kişi, seyahat kararı alırken itme ve çekme faktörlerinin etkisi altında kalmaktadır. İtme faktörü, seyahat isteğine neden olan ihtiyacı göstermektedir. Kişinin tatile çıkmaya karar vermesini sağlamaktadır. Çekme faktörü ise destinasyon ve destinasyonda kullanılabilir olan ürünleri içermektedir (Heitmann, 2010).

Iso-Ahola'nın geliştirdiği teoride, iki motivasyon faktörü bulunmaktadır. Faktörlerden ilki içsel ödül arayışı, ikincisi ise rutin hayattan uzaklaşmaktır. IsoAhola bu faktörleri kişisel ve kişiler arası olarak ikiye ayırmıştır (Hsu ve Huang, 2008). Pearce'ın 1988 yılında geliştirdiği Seyahat Kariyeri Merdiveni Modeli, Maslow'un İhtiyaçlar Hiyerarşisinden uyarlanarak geliştirilmiştir. Teoriye göre 
turist motivasyonu beş farklı seyahat ihtiyacı düzeyinden oluşmaktadır (Bowen ve Clarke, 2009; Musai vd., 2013; Pearce ve Lee, 2005). İhtiyaçlar, merdiven ya da hiyerarşi olarak organize edilmiştir. Teoriye göre en alt düzeyde bulunan seyahat ihtiyacı dinlenme ihtiyacıdır. İkinci düzeyde uyarılma ihtiyacı, üçüncü düzeyde insan ilişkisi ihtiyacı, dördüncü düzeyde özsaygı ve gelişim ihtiyacı, beşinci düzeyde tüm ihtiyaçların giderilmesi yer almaktadır (Pearce ve Lee, 2005; Hsu ve Huang, 2008; Heitmann, 2010; Paris ve Teye, 2010; Musai vd., 2013).

Alanyazında seyahat motivasyonları ile ilgili çok sayıda çalışmaya rastlanılmıştır (Demir, 2010a; Evren ve Kozak, 2012; Harman, 2012). İncelenen çalışmalar itme ve çekme faktörlerinin seyahat motivasyonu üzerindeki etkisi ve diğer seyahat motivasyon teorileri üzerine yoğunlaşmıştır. Alanyazında seyahat motivasyonlarını belirlemek amacıyla yalnızca itme faktörlerini (Demir, 2010b; Ma, 2010) ve yalnızca çekme faktörlerini (Demir, 2010a; Evren ve Kozak, 2012) inceleyen çalışmalar olduğu gibi her iki faktörü ele alan (Kozak ve Rimmington, 2000; Klenosky, 2002; Yoon ve Uysal, 2005; Jang ve Wu, 2006; Yüksel ve Yüksel, 2008; Mohammad ve Som, 2010; Pesonen, 2012; Damijanić ve Šergo Sergo, 2013) çalışmalar da bulunmaktadır. Kasim ve arkadaşlarının (2013) Malezya'daki bir adaya yönelik yerel turistlerin seyahat motivasyonlarını belirlemek için yapmış oldukları çalışma sonucunda en önemli motivasyon faktörü beden ve zihin canlanması olarak, en az önemli motivasyon faktörü ise kültürel yerleri ziyaret etmek olarak belirlenmiştir.

Jönsson ve Devonish'in (2008) Barbados Adası'nı ziyaret eden turistlerin seyahat motivasyonları üzerinde uyruk, cinsiyet ve yaşın etkisini belirlemeye yönelik yapmış oldukları çalışmada Kozak'tan (2002) uyarlanan 14 seyahat motivasyonu unsurunu kültürel, zevk ve fantezi, dinlenme ve fiziksel olarak dört faktörde incelemişlerdir. Bu çalışmada seyahat motivasyonlarını etkileyen en önemli faktör dinlenme, en az önemli olan faktör ise kültür olarak belirlenmiştir. Yapılan araştırma sonucunda Barbados'a gelen turistlerin seyahat motivasyonları uyruklarına ve yaşlarına göre anlamlı farklılıklar gösterirken, cinsiyetin seyahat motivasyonları üzerinde anlamlı bir etkisi olmadığı tespit edilmiş̧ir.

Terblanche'nin (2012) Magoebaskloof'u ziyaret eden maceracı turistlerin seyahat motivasyonlarını belirlemek için yapmış olduğu çalışmada motivasyon unsurları yedi faktör (prestij, grup birlikteliği, bilgi arayışı, kaçış ve rahatlama, çekicilik, ilişki kurma ve yenilik) olarak ele alınmıştır. Araştırma sonucunda turist motivasyonunu etkileyen faktörlerin en önemli üç faktörün sirasıyla kaçış ve rahatlama, grup birlikteliği ve bilgi arayışı olduğu belirlenmiştir.

Yoon ve Uysal'in (2005) motivasyon ve memnuniyetin destinasyon sadakati üzerindeki etkisini belirlemeye yönelik yapmış oldukları çalışmada 24 itme ve 28 çekme motivasyon unsuru belirlenmiştir. Yapılan faktör analizi sonucunda itme faktörleri heyecan, bilgi ve eğitim, dinlenme, başarı, aile birlikteliği, kaçış, güvenlik ve evden uzaklaşma olarak sekiz faktörde incelenmiştir. Çekme faktörleri modern atmosfer ve aktiviteler, yaban hayatı, güvenilir hava, doğal manzara, aktiviteler, farklı kültürler, temizlik ve alışveriş, gece hayatı ve yerel mutfaklar, ilginç kasaba ve köyler, su aktiviteleri olmak üzere 
10 faktörde ele alınmıştır. Yapılan çalışma sonucunda çekme faktörlerinin itme faktörlerinden ayrı olarak destinasyon sadakati üzerinde belirleyici olduğu saptanmıştır.

\section{B. Turist Memnuniyeti}

Müşteri memnuniyeti, pazar bölümlendirmesi yapabilmek ve pazar yapısını anlayabilmek için en çok üzerinde durulan konulardan biridir (Dolnicar ve Le, 2008). Memnuniyet araştırmaları, yönetim ve pazarlama disiplinleri ile ilişkilidir. Hizmet pazarlaması ve yönetimi ile ilgili 17.000'den fazla yayınlanmış makale varken bunların çok küçük bir kısmı turizm sektörü ile ilgilidir (Latu ve Everett, 2000).

Turizm sektöründeki temel varsayımlardan biri farklı insanların farklı turizm ihtiyaçlarının olduğu, diğeri ise memnun olmuş turistin seyahat deneyiminden dolayı ilgili destinasyonu tekrar ziyaret edeceğidir (Dolnicar ve Le, 2008). Müşteri sadakati, müşterinin kendisi için alternatiflerin olduğu bir ortamda belirli bir işletme, ürün veya hizmete yönelik içten bağl1lık, tesadüfi olmayan alışveriş eğilimi arzusu ve eylemidir (Bayuk ve Küçük, 2007). Bu bağlamda destinasyon turistik bir ürün olarak düşünülürse destinasyon sadakati, pek çok alternatifin olduğu bir ortamda ilgili destinasyona yönelik tekrar ziyaret etme niyeti ve başkalarına tavsiye etme niyeti olarak tanımlanabilmektedir (Yoon ve Uysal, 2005).

Turist memnuniyetinin önemini, destinasyondan memnun olarak ayrilan turistin pozitif reklam etkisi yaratarak yeni turist kazanımını kolaylaştırması ve eski müşteriyi yüksek maliyetli pazarlama çalışmalarına ihtiyaç duyulmadan tekrar ilgili destinasyona çekmesi oluşturmaktadır. Memnun olmamış turistler ise yakınlarına şikayetlerini anlatarak destinasyona yönelik kötü bir izlenim oluşmaktadır. Tazminat ödemeleri ile son bulan şikayetler olabileceği gibi şikayetler ile mücadele etmek zaman alıcı ve maliyetlidir (Swarbrooke ve Horner, 2007). Ayrıca memnun olarak ayrılan turistlerin, memnuniyetlerini kitle iletişim araçları ile paylaşabildikleri için memnuniyet kritik bir öneme sahiptir (Baker ve Crompton, 2000).

Müşteri memnuniyetini sağlamak için turistleri tanımak ve ihtiyaçlarını önceden tahmin edebilmek çok önemlidir. Yapılan çalışmalar yeni bir müşteri elde etme maliyetinin, eski müşteriyi muhafaza etmekten daha maliyetli olduğunu göstermektedir (Bogoro vd., 2013). Aynı zamanda turistik işletmeler için rekabet avantajı ve keşif firsatı yaratmaktadır. Üst düzey bir müşteri tatmini müssteri sadakatini oluşturmasının yanı sıra talebin fiyat karşısındaki esnekliğini azaltmaktadır. Daha düşük işlem maliyetleri oluşturmakta ve başarısızlıkların maliyetini düşürmektedir (Huh, 2002).

Sangkaworn ve Mujtaba'ya göre (2010) turizm endüstrisinde müşteri memnuniyeti süreci, seyahat kararı veren turistin herhangi bir turistik ürün satın almasıyla başlamaktadır. Eğer turistik ürün turist beklentilerini karşılıyorsa memnuniyet, karşılamıyorsa memnuniyetsizlik oluşmaktadır (Tidtichumrernporn vd., 2010'da belirtildiği üzere). Diğer bir ifadeyle bir kişi satın aldığ1 ürün veya hizmetten memnun kalmışsa, beklentileri tamamen karşılanmış demektir (Kotler 
vd., 2008). Ancak turistin genel memnuniyet düzeyini yalnızca destinasyon belirlememektedir. Aynı zamanda destinasyonda nasıl davranıldığı ve nasıl hizmet verildiği de genel memnuniyeti etkilemektedir (Prayag, 2009).

Alanyazında turist memnuniyeti ile ilgili çalışmaların büyük bir kısmı destinasyona yönelik turist sadakati ile ilişkilendirilmiştir (Baker ve Crompton, 2000; Kozak ve Rimmington, 2000; Prebensen, 2003; Duman ve Öztürk, 2005; Valle vd., 2006; Prayag, 2008; Prayag, 2009; Okello ve Yerian 2009; Chen ve Chen 2010; Cam 2011; Hosany ve Prayag 2011; Alrousan ve Abuamoud, 2013; Osman ve Sentosa, 2013; Tomar ve Tomar, 2013). Bunun yan1 sira turist memnuniyeti seyahat tipine (Weiler ve Ham, 2001); beklenti ve algılanan değere (Song vd., 2011); önem, performans ve seyahat motivasyonlarına (Meng vd., 2008); turist tipolojilerine (Hosany ve Prayag, 2011); hizmet deneyimine (Prebensen, 2003) ve destinasyon imajına göre (Al-Majali, 2012; Sadeh vd., 2012) alanyazında incelenmiştir. Bu çalışmalar arasında yer alan Devesa ve arkadaşlarının (2010) İspanya'da yer alan Segovia kırsal alanındaki turizm faaliyetlerine katılan turistlerin seyahat motivasyonları ve genel memnuniyet düzeylerini belirlemeye yönelik yapmış oldukları çalışmada, farklı ihtiyaçları olan turistlerin farklı beklentileri olduğu ve bu farklılıkların genel memnuniyet düzeyini etkileyebileceği belirlenmiştir.

Okello ve Yerian'ın (2009) Tanzanya'da koruma altına alınmış altı milli parka yönelik ziyaretçi memnuniyeti düzeyini ve ziyaretçilerin tekrar ziyaret etme niyetlerini belirlemeye yönelik yapmış oldukları araştırmada turistlerin memnuniyet düzeyleri oldukça yüksek olarak belirlenmiştir. Ayrıca araştırmaya katılan turistlerin \%86'sinın destinasyonu tekrar ziyaret etme niyetinde olduklarını da belirlemişlerdir. Ekiz ve Köker'in (2012) ise Kuzey Kıbrıs Türk Cumhuriyeti'ni ziyaret eden yabancı turistlerin Kıbrıs'a yönelik memnuniyetlerine neden olan faktörleri belirlemek amacıyla yaptıkları çalışmada çevre ve güvenlik, ikamet ve restoran tesisleri, alışveriş ve turizm mekanları, ulaşım tesisleri ve yerel mutfağın turist memnuniyetini pozitif yönde etkilediğini tespit etmişlerdir.

\section{ARAŞTIRMANIN HIPOTEZLERI}

O'Leary ve Deegan (2003) seyahat motivasyonlarını, turistlerin ihtiyaçları ve arzularını etkileyen seyahat eğilimi olarak ifade etmişlerdir (Mlozi ve Pesamaa 2013'te belirtildiği üzere). Pearce ve Caltabiano'ya göre (1983) seyahat motivasyonları, turistik davranışları anlamaya yardımcı olmasının yanı sıra insanlar neden seyahat eder ve insanların satın alma davranışlarını ne başlatır sorularına cevap aramaktadır (Kasim vd., 2013'te belirtildiği üzere). Daha önce yapılmış çalışmalarda (Demir, 2010a; Harman, 2012) seyahat motivasyonuna etki eden faktörler ile turist memnuniyeti arasında pozitif bir ilişki olduğu tespit edilmiştir. $\mathrm{Bu}$ durumda en önemli soru turistleri nelerin memnun ettiğidir (Prebensen, 2003).

Motivasyon çalışmaları turistlerin istek, ihtiyaç ve beklentilerini anlamaya çalışmaktadır (Latu ve Everett, 2010). Her ne kadar turistlerin sosyodemografik özellikleri ve karakterleri turist davranışını etkilese de turistin öznel 
deneyimiyle ilgili diğer faktörler bu karmaşık süreci daha güçlü bir şekilde açıklamaktadır. $\mathrm{Bu}$ bağlamda motivasyon ve memnuniyet turizm alanında bireysel davranışları belirleyen iki temel faktör haline gelmektedir (Devesa vd., 2010). Yapılan açıklamalara ve çalışmalara bağlı olarak $\mathrm{H}_{1}$ ve $\mathrm{H}_{2}$ geliştirilmiştir.

$H_{1}$ Likya Yolu'nu yürüyen turistlerin seyahat motivasyonlart ile genel memnuniyet düzeyleri arasında pozitif bir iliş̧k vardır.

$\mathrm{H}_{2}$ Likya Yolu'nu yürüyen turistlerin seyahat motivasyonlarl, genel memnuniyet düzeylerini pozitif olarak etkilemektedir.

Nadir örnekler (Jang ve Feng, 2007) dışında müşteri memnuniyeti, müşteri sadakatinin güvencesidir. Memnuniyet, her zaman sadakatle sonuçlanamayabilir. Fakat şüphesiz sadık müşteri, memnun müşteridir (Jones ve Sasser, 1995). Valle ve arkadaşlarına göre (2006) turist memnuniyeti ve deneyimi destinasyonu tekrar ziyaret etme niyetinin belirleyicisidir. Yapılan açıklamalara ve çalışmalara bağlı olarak $\mathrm{H}_{3}$ ve $\mathrm{H}_{4}$ hipotezleri önerilmiştir.

$\mathrm{H}_{3}$ Likya Yolu'nu yürüyen turistlerin genel memnuniyet düzeyi gelecekte tekrar ziyaret etme niyetlerini pozitif olarak etkilemektedir.

$\mathrm{H}_{4}$ Likya Yolu'nu yürüyen turistlerin genel memnuniyet düzeyi tavsiye etme niyetlerini pozitif olarak etkilemektedir.

\section{ARAȘTIRMANIN YÖNTEMI}

\section{A. Araştırmanın Amacı, Önemi ve Kapsamı}

$\mathrm{Bu}$ çalışmanın temel amacı Likya Yolu'nu yürüyen turistlerin seyahat motivasyonlarını etkileyen faktörleri belirlemektir. Ayrıca turistlerin memnuniyet düzeylerinin tekrar ziyaret etme ve tavsiye etme niyetleri üzerindeki etkisinin belirlenmesi de amaçlanmaktadır.

Turistin karar verme sürecini etkileyen destekleyici tutundurma faaliyetleri turizm pazarında rekabet firsat1 yaratabilmektedir (Kotler vd., 2008). $\mathrm{Bu}$ araştırma ile elde edilen bilgilerin pazar bölümlendirmesi yapan ve pazarlama çalışmalarını planlayan turizm işletmelerinin doğru kararlar almasına yardımcı olacağı düşünülmektedir. Özellikle tutundurma mesajının belirlenmesi ve iletişim kanalının seçilmesinde Likya Yolu ve güzergahında yer alan destinasyon yöneticileri ve turizm işletmelerine önemli katkılar sağlayacağı öngörülmektedir. Yapılan taramalarda Likya Yolu'nu yürüyen turistlerle ilgili ampirik bir araştırmaya ulaşılamamış olmasının da yapılan bu çalışmanın önemini artırdığı düşünülmektedir. Likya Yolu'nu yürüyen turistlerin seyahat motivasyonları ve genel memnuniyet düzeyleri ile ilgili Türkiye'deki ilk çalışma olması araştırmanın akademik önemini oluşturmaktadır.

Bu araştırmanın evrenini Likya Yolu'nu yürüyen yerli ve yabancı turistler oluşturmaktadır. Ancak Likya Yolu'nu yürüyen turistlerle ilgili resmi istatistiklere ulaşılamamıştır. Bu nedenle Turgut ve Clow (2006) tarafından belirtilen 12.000 kişi evren olarak kabul edilmiştir. Sınırsız evren büyüklügünde 0,95 güven aralığındaki örneklem büyüklügü 384 olarak hesaplanmıştır (Ural ve Kılıçlar, 2006). Ana kütleyi oluşturan kişiler belirli olmadığı için örnekleme tekniği olarak kolayda örnekleme yönteminin seçilmesine karar verilmiştir. 
Anket uygulaması 2014 yılının Mart ve Nisan aylarında gerçekleştirilmiştir. Anket uygulaması Likya Yolu'nun Hisarönü-Faralya, Faralya-Kabak Koyu, Kaş-Aperlai, Mavikent-Gelidonya Feneri, Gelidonya Feneri-Adrasan, Adrasan-Olympos etaplarında Likya Yolu'nun üzerinde yüz yüze görüşme tekniği ile gerçekleştirilmiştir. Anketlerin bir kısmında tur rehberleri ile işbirliği yapılmıştır. Yapılan alan araştırması sonunda 407 kullanılabilir ankete ulaşılmıştır. Hedef olarak konulan 384 kişiden oluşan örneklem büyüklügünün yaklaşık $\% 3$ oranında geçildiği görülmektedir.

\section{B. Veri Toplama Aracı}

Araştırmada veri toplama tekniklerinden anket yöntemi tercih edilmiştir. Anketin birinci bölümünde Likya Yolu'nu yürüyen turistlerin seyahat motivasyonlarını belirlemek amacıyla yararlanılan Motivasyon Ölçeği yer almaktadır. Bu ölçek Paris ve Teye (2010) tarafından geliştirilmiş ve Harman (2012) tarafından Türkçeye uyarlanmıştır. Ölçek 7 boyut ve 26 maddeden oluşmaktadır. Ölçeğin yanıt kategorileri 5'li Likert derecelemesine göre düzenlenmiştir. 5'li Likert derecelemesi "Kesinlikle katılmıyorum" (1), "Katılmiyorum" (2), "Ne katılıyorum ne katılmiyorum" (3), "Katılıyorum" (4) "Kesinlikle katılıyorum" (5) olarak belirlenmiştir.

Anketin ikinci bölümünde ise katılımcıların demografik ve sosyoekonomik özelliklerine ilişkin sorular yer almaktadır. Anketin üçüncü bölümünde Likya Yolu'nu yürüyen turistlerin memnuniyet düzeyi ve destinasyon sadakati üzerine çoktan seçmeli sorular yer almaktadır. Bu bölümdeki sorular Valle ve arkadaşlarının (2006) çalışmalarından yararlanılarak oluşturulmuştur. Turistlerin memnuniyetini belirlemek amacıyla hazırlanan üç sorudan ikisinin yanıt kategorileri hiç memnun değilim (1), çok memnunum (5) olarak; diğer sorunun ise yanıt kategorisi evet-hayır şeklinde ifade edilmiştir. Destinasyon bağlılı̆̆ını belirlemek amacıyla hazırlanan iki ifadenin de yanıt kategorisi Evet, Hayır ve Belki olmak üzere üçlü derecelendirilmiştir. Turistlerin memnuniyeti ve destinasyon sadakatlerine ilişkin ifadeler bir ölçek olarak değil, bağımlı değişken ifadesi olarak ele alındığ 1 için geçerlilik ve güvenirlik analizi yapılmamıştır. Anket formu Türkçe ve İngilizce dillerinde hazırlanmıştır.

\section{B. Araştırmanın Sınırlııkları}

Araştırmanın ilk kısıtlılı̆̆ kullanılan örnekleme yöntemidir. $\mathrm{Bu}$ araştırmada ana kütlenin tamamına ulaşmak mümkün olmadığı için kolayda örnekleme yönteminin kullanılmasına karar verilmiştir. Araştırmanın ikinci kısıtlılı̆g 1 alan araştırması yapılırken yürüyüşe elverişli olması bakımından Likya Yolu'nun yüksek sezonlarından Mart ve Nisan aylarının tercih edilmesidir. Araştırmanın üçüncü kısıtlılığı anket yöntemini araştırmacının kendisi yaptığı için Likya Yolu'nun bütün etaplarına ulaşmanın zaman, maddi kaynak ve erişebilirlik açısından yeterli olmaması nedeniyle yalnızca altı etapta yapılmış olmasıdır. Ayrıca Likya Yolu'nu yürüyen turistler yol üzerinde yorgun ve bitkin olmaları nedeniyle anketi cevaplama konusunda isteksiz davranışlar göstermişlerdir. $\mathrm{Bu}$ nedenle örneklem büyüklüğünün artırılamaması araştırmanın diğer bir sınırlılığı olarak kabul edilebilir. 


\section{BULGULAR}

\section{A. Katılımcıların Demografik Özellikleri}

Alan araştırması sonunda 407 turistten toplanan veri geçerli olarak kabul edilmiştir. Tablo 1 incelendiğinde katılımcıların \%51,8'inin (211 kişi) kadın; $\% 53,1$ 'inin (216 kişi) evli olduğu görülmektedir. Katılımcıların \%56,5'i 45 yaş ve altında, \% 48,4'ünün (197 kişi) önlisans ve lisans eğitimli, \%48,4'ü 3001 TL ve üzerinde gelire sahiptir. Ayrıca araştırmaya katılanların önemli bir bölümü (\%65,6’s1 -267 kişi-) Türk Vatandaşıdır.

Tablo 1: Ziyaretçilerin Demografik Özelliklerine Göre Dağılımı (n:407)

\begin{tabular}{|l|c|c|l|l|l|}
\hline $\begin{array}{l}\text { Demografik } \\
\text { Özellikler }\end{array}$ & $n$ & $\%$ & & $n$ & $\%$ \\
\hline Cinsiyet & 211 & 51,8 & 1000 TL ve alt1 & 35 & 8,6 \\
\hline Kadın & 196 & 48,2 & 1001 TL -1500 TL & 25 & 6,1 \\
\hline Erkek & & 1501 TL -2000 TL & 56 & 13,8 \\
\hline Medeni Durum & 216 & 53,1 & 2001 TL -2500 TL & 64 & 15,7 \\
\hline Evli & 191 & 46,9 & 2501 TL -3000 TL & 30 & 7,4 \\
\hline Bekar & 89 & 21,9 & 3501 TL -4000 TL & 28 & 6,9 \\
\hline Yaş & 141 & 34,6 & 4001 TL -5000 TL & 42 & 10,3 \\
\hline 30 ve altı & 177 & 43,5 & $5001 \mathrm{TL}$ ve üzeri & 102 & 25,1 \\
\hline $31-45$ yaş grubu & & Milliyet & 267 & 65,6 \\
\hline 46 ve üzeri & 94 & 23,1 & Türk & 84 & 20,6 \\
\hline Eğitim Düzeyi & 197 & 48,4 & Alman & 14 & 3,4 \\
\hline İlköğretim ve Lise & 116 & 28,5 & İngiliz & 47 & 10,2 \\
\hline Önlisans ve Lisans & & & Diğer & \\
\hline Lisansüstü &
\end{tabular}

\section{B. Geçerlilik ve Güvenirlik Analizi}

Öncelikle çalışma kapsamında yararlanılan Motivasyon Ölçeğinin geçerlilik ve güvenirlik analizleri yapılmıştır. Ölçeğin yapısal geçerliliği açıklayıcı faktör analizi ile belirlenmiştir. Yapılan KMO testinin anlamlı çıkması sonucu veri setine faktör analizi uygulanmıştır. Uygun faktör sayısının belirlenmesinde öz değerin 1'den büyük olanların seçilmesine, faktörlerin en az 3 maddeden oluşmasına, faktör yükünün en az 0,40 olmasına, binişik durumdaki maddelerin faktör yük farkının en az 0,10 olmasına ve Varimax dönüşümü kullanılmasına karar verilmiştir (Büyüköztürk, 2012). 
Tablo 2: Seyahat Motivasyonlarına Yönelik Açıklayıcı Faktör Analizi Sonuçları

\begin{tabular}{|c|c|c|c|c|c|}
\hline Faktörler/İfadeler & 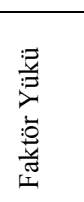 & 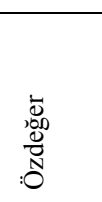 & 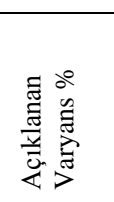 & 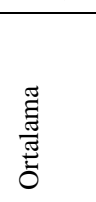 & 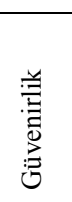 \\
\hline \multicolumn{2}{|l|}{ Sosyalleşme ve Kendini Gerçekleștirme } & 4,230 & 17,624 & 3,553 & ,892 \\
\hline Aidiyet hissine sahip olmak & ,765 & & & & \\
\hline Kendime olan güvenimi arttırmak & ,733 & & & & \\
\hline Yakın dostluklar geliştirmek & ,714 & & & & \\
\hline Diğer gezginlere eşlik etmek & 653 & & & & \\
\hline Diğerleri ile yeni arkadaşlıklar geliştirme &, 583 & & & & \\
\hline Yaşamımdaki yeni dönemlere hazırlanmak & ,565 & & & & \\
\hline Hayal gücümü kullanmak & ,538 & & & & \\
\hline Ziyaret ettiğim yerlere bir şekilde katkı sağlamak &, 531 & & & & \\
\hline \multicolumn{2}{|l|}{ Bağımsız Seyahat Etme } & 3,060 & 12,750 & 3,568 & ,783 \\
\hline Seyahatimi kendi kendime organize etmek & ,722 & & & & \\
\hline Mümkün olduğunca uzun süre seyahat etmek & ,706 & & & & \\
\hline Daha önce gidilmemiş ücra yerlere gitmek & 639 & & & & \\
\hline Düşük bir bütçe ile seyahat etmek &, 575 & & & & \\
\hline \multicolumn{2}{|l|}{ Dünyayı Tanıma } & 2,654 & 11,060 & 4,022 & ,783 \\
\hline Dünya hakkındaki bilgimi arttırmak & ,814 & & & & \\
\hline Yerel halktan insanlar ile etkileşime girmek &, 730 & & & & \\
\hline Diğer kültürleri keşfetmek & 669 & & & & \\
\hline Bağımsız ve açık görüşlü olmak & 578 & & & & \\
\hline \multicolumn{2}{|l|}{ Deneyim Arayışı } & 2,459 & 10,246 & 3,796 & ,751 \\
\hline $\begin{array}{l}\text { Ailem ve arkadaşlarım ile paylaşabileceğim } \\
\text { deneyimler yaşamak }\end{array}$ & ,772 & & & & \\
\hline Arkadaşlarımla iyi vakit geçirmek &, 592 & & & & \\
\hline Özel etkinliklere katılmak &, 562 & & & & \\
\hline Heyecan yaşamak &, 546 & & & & \\
\hline Hayatımda bir kere yapabileceğim faaliyetleri yapmak & ,499 & & & & \\
\hline \multicolumn{2}{|l|}{ Sakinlik Arayışı } & 2,216 & 9,235 & 4,162 & ,753 \\
\hline Zihinsel olarak rahatlamak & ,773 & & & & \\
\hline Sakin bir atmosferde bulunmak & ,734 & & & & \\
\hline Fiziksel olarak rahatlamak & ,714 & & & & \\
\hline \multicolumn{6}{|c|}{$\begin{array}{l}\text { Açıklanan toplam varyans: \% 60,915 Kaiser-Meyer-Olkin Örneklem Yeterliliği: \% 92,5 p<0,05 } \\
\text { Barlett’s Küresellik Testi X: } 4471,474 \text { Ölçeğin genel ortalamas: } 3,761 \text {; } \\
\text { Ölçeğin tamamı için Alpha: 0,9926 }\end{array}$} \\
\hline
\end{tabular}

Yapılan açıklayıcı faktör analizi sonucunda ölçekte yer alan 24. maddenin binişik madde olduğu ve faktör yükü farkının 0,10 altında olduğu; 14. maddenin faktör yükünün 0,40 'ın altında olduğu saptanmıştır. Bu nedenle 14 (kendini keşfetmek) ve 24. madde (yeteneklerimi göstermek) ölçekten çıkarılarak faktör analizi tekrarlanmıştır. 24 maddeden oluşan ölçek beş faktörde toplanmış ve toplam varyansın \% 60,915'ini açıklamıştır.

Söz konusu beş faktörün hangi başlıklar altında toplandığının tespit edilmesi amacıyla döndürülmüş bileşenler matrisi kullanılmıştır. Yapılan faktör analizi sonucunda ölçeğin orijinaline bağlı kalınarak birinci motivasyon faktörü 
sosyalleşme ve kendini gerçekleştirme, ikinci faktör bağımsız seyahat etme, üçüncü faktör dünyayı tanıma, dördüncü faktör deneyim arayışı ve beşinci faktör sakinlik arayışı olarak isimlendirilmiştir. Faktör analizinde yer alan değişkenlere ilişkin verilerin ortalama, güvenilirlik, faktör yükü ve öz değerleri Tablo 2'de gösterilmektedir.

Yapılan güvenirlik analizi sonucunda hem ölçeğin alt boyutları itibariyle hem de ölçeğin tamamı için hesaplanan Cronbach's Alpha katsayısının 0,70'in üzerinde olduğu bulgulanmıştır. Alanyazında 0,70 ve üstü değerlere sahip ölçekler yüksek derecede güvenilir olarak nitelendirilmektedir (Hair vd., 2010).

Açıklayıcı faktör analizi ile elde edilen ölçek boyutlarını test etmek amacıyla birinci düzey doğrulayıcı faktör (DFA) analizi uygulanmıştır. Ölçeğin DFA sonuçları $\mathrm{X}^{2}=839,37$ ve serbestlik derecesi (df) $=242$ olarak gerçekleştirilmiştir. Bu sonuçlar ölçek için uygun ve kabul edilebilir bir durumu ifade ederken, $X^{2} / \mathrm{df}<5 \quad(839,37 / 242=3,47)$ olarak bulunmuştur. Çalışmada ölçek için elde edilen RMSEA (Yaklaşık Hataların Ortalama Karekökü) değerinin 10'dan küçük olması (RMSEA=0,078) ölçeğe ilişkin modelin kabul edilebilir bir uyum gösterdiğini açıklamaktadır.

Tablo 3'de görüldüğü gibi gözlenen değişkenlere ait standardize çözümleme değerleri 0,63 ve 0,86 arasında, t-değerleri 1,96'ın üzerinde bulgulanmıştır. $\mathrm{Bu}$ tüm parametrelerin istatistiksel olarak anlamlı olduğunu göstermektedir. Ayrıca Tablo 3 incelendiğinde ölçekteki faktörlerin birleşik yapı güvenirliklerinin 0,70 düzeyini aştığı, faktörlerin ortalama açıklama varyanslarının 0,50'yi aştığı belirlenmiştir. Elde edilen bulgular motivasyon ölçeğini oluşturan boyutların içsel tutarlıkları ve yapıyı açıklama güçlerinin yeterli olduğunu doğrulamaktadır.

Tablo 3: Doğrulayıcı Faktör Analizi

\begin{tabular}{|c|c|c|c|c|c|}
\hline Gizil ve Gözlenen Değişkenler & $\vec{v}$ & 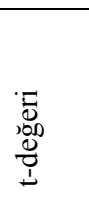 & $\approx$ & 兄 & $\sum_{<}^{\Gamma}$ \\
\hline \multicolumn{3}{|l|}{ Sosyalleşme ve Kendini Gerçekleştirme } & & 89 & ,51 \\
\hline Aidiyet hissine sahip olmak & ,78 & 18,26 & 61 & & \\
\hline Kendime olan güvenimi arttırmak & ,78 & 18,24 & 61 & & \\
\hline Yakın dostluklar geliştirmek & ,72 & 16,32 & ,52 & & \\
\hline Diğer gezginlere eşlik etmek & ,66 & 14,41 & 44 & & \\
\hline Diğerleri ile yeni arkadaşliklar geliştirme & ,70 & 15,71 & 49 & & \\
\hline Yaşamımdaki yeni dönemlere hazırlanmak & ,70 & 15,79 & 49 & & \\
\hline Hayal gücümü kullanmak & ,69 & 15,44 & ,48 & & \\
\hline Ziyaret ettiğim yerlere bir şekilde katk1 sağlamak & ,66 & 14,44 & 44 & & \\
\hline \multicolumn{3}{|l|}{ Bağımsız Seyahat Etme } & & ,82 & ,54 \\
\hline Seyahatimi kendi kendime organize etmek & ,68 & 14,47 & 46 & & \\
\hline Mümkün olduğunca uzun süre seyahat etmek &, 77 & 16,91 & ,59 & & \\
\hline Daha önce gidilmemiș ücra yerlere gitmek & ,73 & 15,48 & ,53 & & \\
\hline Düşük bir bütçe ile seyahat etmek & ,75 & 16,09 & ,56 & & \\
\hline
\end{tabular}




\begin{tabular}{|c|c|c|c|c|c|}
\hline \multicolumn{3}{|l|}{ Dünyayı Tanıma } & &, 81 &, 52 \\
\hline Dünya hakkındaki bilgimi arttırmak & 63 & 12,94 & 40 & & \\
\hline Yerel halktan insanlar ile etkileşime girmek & ,73 & 15,50 & ,53 & & \\
\hline Diğer kültürleri keşfetmek & ,81 & 17,97 & ,66 & & \\
\hline Bağımsız ve açık görüşlü olmak & ,69 & 14,39 & 48 & & \\
\hline \multicolumn{3}{|l|}{ Deneyim Arayışı } & & ,83 &, 54 \\
\hline $\begin{array}{l}\text { Ailem ve arkadaşlarım ile paylaşabileceğim deneyimler } \\
\text { yaşamak }\end{array}$ & ,68 & 12,80 & ,46 & & \\
\hline Arkadaşlarımla iyi vakit geçirmek &, 75 & 15,48 & 56 & & \\
\hline Özel etkinliklere katılmak & ,63 & 14,52 & 40 & & \\
\hline Heyecan yaşamak & ,86 & 17,86 & ,74 & & \\
\hline Hayatımda bir kere yapabileceğim faaliyetleri yapmak & ,74 & 15,32 & 55 & & \\
\hline \multicolumn{3}{|l|}{ Sakinlik Arayışı } & & 75 &, 50 \\
\hline Zihinsel olarak rahatlamak & ,63 & 12,70 & ,41 & & \\
\hline Sakin bir atmosferde bulunmak & ,79 & 16,68 &, 50 & & \\
\hline Fiziksel olarak rahatlamak & ,70 & 14,42 & ,66 & & \\
\hline $\begin{array}{l}\text { CSL: Completely Standardized Loading (Standardize Ec } \\
\text { CR: Composite Reliability (Birleşik Yapı Güvenirlikleri) } \\
\text { AVE: Average Variance Extracted (Ortalama Açıklanan }\end{array}$ & Değe & & & & \\
\hline
\end{tabular}

Diğer uyum indeksleri Tablo 4'de görülmektedir. Uyum iyiliklerine bağl1 olarak ölçeğin amprik veri ile tutarlı ve istatistiksel olarak geçerli olduğu anlaşılmaktadır. Uyum iyiliği indekslerinin dışında ölçeğin geçerliliğinin ve güvenirliğinin sınanmasında standardize edilmiş değerleri (CSL- Completely Standardized Loading), t-değerleri, faktörlerin birleşik yapı güvenirlikleri (CRComposite Reliability) ve açıklanan varyanslarının da (AVE- Average Variance Extracted) incelenmesi gerekmektedir.

Tablo 4: Uyum İyiliği İndeksleri

\begin{tabular}{|l|c|l|l|}
\hline Uyum İyiliği & $\begin{array}{c}\text { Ölçme Modeli } \\
\text { Uyum İyiliği } \\
\text { Değerleri }\end{array}$ & $\begin{array}{c}\text { İyi Uyum İyiliği } \\
\text { Değeri }\end{array}$ & $\begin{array}{c}\text { Kabul Edilebilir } \\
\text { Uyum İyiliği Değeri }\end{array}$ \\
\hline$X^{2} / \mathrm{df}$ & 3,47 & $0 \leq X^{2} / \mathrm{df} \leq 2$ & $2<X^{2} / \mathrm{df} \leq 5$ \\
\hline $\begin{array}{l}\text { RMSEA-Root Mean Square } \\
\text { Error of Approx }\end{array}$ & 0,078 & $0 \leq \mathrm{RMSEA} \leq 0.05$ & $0.05<\mathrm{RMSEA} \leq 0.08$ \\
\hline GFI-Goodness Fit Index & 0,85 & $0.95 \leq \mathrm{GFI} \leq 1.00$ & $0.90 \leq \mathrm{GFI}<0.95$ \\
\hline $\begin{array}{l}\text { AGFI-Adjusted Goodness of } \\
\text { Fit Index }\end{array}$ & 0,82 & $0.90 \leq \mathrm{AGFI} \leq 1.00$ & $0.85 \leq \mathrm{AGFI}<0.90$ \\
\hline $\begin{array}{l}\text { SRMR-Standardize Root } \\
\text { Mean Square Residual }\end{array}$ & 0,96 & $0 \leq \mathrm{SRMR} \leq 0.05$ & $0.05<\mathrm{SRMR} \leq 0.10$ \\
\hline CFI-Comparative Fit Index & 0,056 & $0.97 \leq \mathrm{CFI} \leq 1.00$ & $0.95 \leq \mathrm{CFI}<0.97$ \\
\hline
\end{tabular}

\section{Hipotez Testleri}

Araştırmanın birinci hipotezini ( $H_{1}:$ Likya Yolu'nu yürüyen turistlerin seyahat motivasyonlar ile genel memnuniyet düzeyleri arasında pozitif bir ilişki vardır) test etmek üzere korelasyon analizini yapılmıştır. Yapılan analizin sonucunda seyahat motivasyonu faktörlerinden sadece dünyayı tanıma faktörü ile genel memnuniyet düzeyi arasında düşük düzeyde pozitif anlamlı bir ilişki olduğu belirlenmiştir $(\mathrm{r}=0,155 \mathrm{p}<0,05)$. Diğer motivasyon faktörleri ile genel 
memnuniyet düzeyi arasında anlamlı bir ilişki tespit edilememiştir. $\mathrm{Bu}$ nedenle $\mathrm{H}_{1}$ kısmen kabul edilmiştir. Tablo 5'de korelasyon analizi sunulmuştur.

Tablo 5: Korelasyon Analizi

\begin{tabular}{|l|c|}
\hline Değişken & Genel Memnuniyet \\
\hline Genel memnuniyet & 1 \\
\hline Sosyalleşme ve Kendini Gerçekleştirme &, 049 \\
\hline Bağımsız Seyahat Etme &, 035 \\
\hline Dünyayı Tanıma &, $155^{* *}$ \\
\hline Deneyim Arayış1 &,- 014 \\
\hline Sakinlik Arayışı &, 076 \\
\hline
\end{tabular}

${ }^{* *} \mathrm{p}<0,01$

Araştırmanın ikinci hipotezini $\left(H_{2}\right.$ : Likya Yolu'nu yürüyen turistlerin seyahat motivasyonları genel memnuniyet düzeylerini pozitif etkilemektedir) test etmek için çoklu regresyon analizine başvurulmuştur. Tablo 6'ya göre seyahat motivasyonu faktörleri ile genel memnuniyet düzeyi arasında pozitif ancak güçlü olmayan bir ilişki olduğu $(\mathrm{r}=0,238)$ tespit edilmiştir. Ayrıca belirlilik katsayısı $\left(\mathrm{r}^{2}\right)$ 0,057 olarak hesaplanmış olup, turistlerin genel memnuniyet düzeylerindeki değişimlerin \%5,7'sinin motivasyon faktörlerine bağlı olduğu söylenebilir. Analiz sonuçlarına göre genel memnuniyetin \%19'u sosyalleşme ve kendini gerçekleştirme faktörüne bağlıdır. Bir başka ifadeyle kişinin motivasyonda sosyalleşme ve kendini gerçekleştirme motivasyonu geçerliyse Likya Yolu'ndan memnun olma düzeyi \%19 olacaktır. Diğer bir ifadeyle de sosyalleşme ve kendini gerçekleştirme motivasyonundaki bir birimlik artış genel memnuniyet üzerinde $\% 19$ oranında bir artışa neden olmaktadır. Bu sonuca bağlı olarak $\mathrm{H}_{2}$ kabul edilmiştir.

Tablo 6: Seyahat Motivasyonu Faktörlerinin Genel Memnuniyet Üzerine Etkisi

\begin{tabular}{|l|c|c|c|c|c|}
\hline \multirow{2}{*}{ Bağımsız Değişkenler } & \multicolumn{2}{|c|}{$\begin{array}{c}\text { Standartlaştırılmamış } \\
\text { Katsayılar }\end{array}$} & $\begin{array}{c}\text { Standartlaştırılmış } \\
\text { Katsayılar }\end{array}$ & \multirow{2}{*}{$\mathrm{t}$} & Anlamlılık \\
\cline { 2 - 4 } & $\beta$ & Std. Hata & $\beta$ & & \\
\hline Sabit & 3,688 &, 240 & & 15,381 &, 001 \\
\hline $\begin{array}{l}\text { Sosyalleşme ve Kendini } \\
\text { Gerçekleştirme }\end{array}$ &, 189 &, 077 &, 211 & 2,244 &, 026 \\
\hline Bağımsız Seyahat Etme &, 001 &, 060 &, 001 &, 015 &, 988 \\
\hline Dünyayı Tanıma &, 025 &, 074 &, 033 &, 345 &, 731 \\
\hline Deneyim Arayış1 &,- 028 &, 073 &,- 034 &,- 389 &, 698 \\
\hline Sakinlik Arayış1 &, 033 &, 060 &, 044 &, 558 &, 577 \\
\hline R: $0,239, \mathrm{R}^{2}: 0,057, \Delta \mathrm{R}^{2}: 0,039, \mathrm{~F}: 3,135, \mathrm{P}: 0,009$ & & & \\
\hline
\end{tabular}

Araştırmanın üçüncü hipotezini( $H_{3}$ :Likya Yolu'nu yürüyen turistlerin genel memnuniyet düzeyi gelecekte tekrar ziyaret etme niyetlerini pozitif olarak etkilemektedir) test etmek için yapilan regresyon analizi sonucunda genel 
memnuniyet düzeyi ile gelecekte tekrar ziyaret etme niyeti arasında negatif ancak güçlü olmayan bir ilişki olduğu $(r=0,095)$ tespit edilmiştir (Tablo 7).

Ayrıca belirlilik katsayısı $\left(\mathrm{r}^{2}\right)$ 0,009 olarak hesaplanmış olup, turistlerin gelecekte tekrar ziyaret etme niyetindeki değişimlerin \%o 9'unun genel memnuniyete bağlı olduğu belirlenmiştir. Genel memnuniyetin gelecekte tekrar ziyaret etmeye yönelik etkisi negatif yönlüdür $(\beta=-0,111)$. Genel memnuniyet düzeyi arttıkça gelecekte tekrar ziyaret etme niyeti bundan negatif etkilenmektedir. Buna bağlı olarak pozitif yönde önerilen $\mathrm{H}_{3}$ hipotezi reddedilmiştir.

Tablo 7: Genel Memnuniyet Düzeyinin Gelecekte Tekrar Ziyaret Etme Niyeti Üzerine Etkisi

\begin{tabular}{|l|c|c|c|c|c|}
\hline \multirow{2}{*}{ Bağımsız Değişken } & \multicolumn{2}{|c|}{$\begin{array}{c}\text { Standartlaştırılmamış } \\
\text { Katsayılar }\end{array}$} & $\begin{array}{c}\text { Standartlaştırılmış } \\
\text { Katsayılar }\end{array}$ & \multirow{2}{*}{$\mathrm{t}$} & \multirow{2}{*}{ Anlamlılık } \\
\cline { 2 - 5 } & $\beta$ & Std. Hata & $\beta$ & &, 001 \\
\hline Sabit & 2,042 &, 263 & & 7,771 &, 056 \\
\hline Genel Memnuniyet &,- 111 &, 058 &,- 095 & $-1,916$ & \\
\hline R: $0,095, \mathrm{R}^{2}: 0,009, \Delta \mathrm{R}^{2}: 0,007, \mathrm{~F}: 3,672, \mathrm{P}: 0,056$ & & \\
\hline
\end{tabular}

Araştırmanın son hipotezini ( $H_{4}:$ Likya Yolu'nu yürüyen turistlerin genel memnuniyet düzeyi tavsiye etme niyetlerini pozitif olarak etkilemektedir) test etmek için yapılan regresyon analizine göre genel memnuniyet ile tavsiye etme niyeti arasında negatif ancak güçlü olmayan bir ilişki olduğu $(\mathrm{r}=0,301)$ tespit edilmiştir (Tablo 8). Ayrıca belirlilik katsayısı ( $\left.\mathrm{r}^{2}\right)$ 0,091 olarak hesaplanmış olup, turistlerin genel memnuniyet düzeylerindeki değişimlerin \% 9,1'inin motivasyon faktörlerine bağlı olduğu söylenebilir. Genel memnuniyetin tavsiye etmeye yönelik etkisi negatif yönlüdür $(\beta=-0,193)$. Genel memnuniyet düzeyi arttıkça tavsiye etme niyeti bundan negatif etkilenmektedir. Bu sonuca bağlı olarak $\mathrm{H}_{4}$ reddedilmiştir.

Tablo 8: Genel Memnuniyet Düzeyinin Tavsiye Etme Niyeti Üzerine Etkisi

\begin{tabular}{|c|c|c|c|c|c|}
\hline \multirow[t]{2}{*}{$\begin{array}{l}\text { Bağımsız } \\
\text { Değişken }\end{array}$} & \multicolumn{2}{|c|}{$\begin{array}{c}\text { Standartlaştırılmamış } \\
\text { Katsayılar }\end{array}$} & $\begin{array}{c}\text { Standartlaştırılmış } \\
\text { Katsayılar }\end{array}$ & \multirow[t]{2}{*}{$\mathrm{t}$} & \multirow[t]{2}{*}{ Anlamlılık } \\
\hline & $\beta$ & Std. Hata & $\beta$ & & \\
\hline Sabit & 1,991 & ,138 & & 14,409 & ,001 \\
\hline $\begin{array}{l}\text { Genel } \\
\text { Memnuniyet }\end{array}$ &,- 193 & ,030 &,- 301 & $-6,349$ & ,001 \\
\hline
\end{tabular}

\section{SONUÇ VE DEĞERLENDİRME \\ Kuramsal Çıktılar}

Turizm endüstrisinin kişilerin isteklerine, ihtiyaçlarına, ilgi alanlarına ve demografik özelliklerine göre şekillendiğini söylemek mümkündür. Turistlerin bireysel özelliklerine göre ürün sunmak, memnuniyet düzeylerini artırmak ve doğru pazarı bölümlendirmesi yapabilmek için seyahat motivasyonlarının bilinmesi gerekmektedir (Francis, 2003). Bu araştırmada Likya Yolu'nu yürüyen turistlerin demografik özellikleri ve seyahate yönelten güdüler belirlenerek; bu 
güdülerinin memnuniyetlerine ve tekrar ziyaret etme niyetlerine olan etkisi ortaya konulmuştur.

$\mathrm{Bu}$ araştırma, Likya Yolu'nu yürüyen turistlerin dünyayı tanıma amaçlarının seyahat sonrasındaki genel memnuniyetleri ile pozitif yönlü bir ilişkiye sahip olduğunu göstermektedir. Likya Yolu'nun farklı etaplardan oluşması ve neredeyse her bir etapta farklı uygarlıklara ait eserlerin görülebilmesi turistlerin kendilerinden önce yaşamış uygarlıklar hakkındaki bilgilerini artırmaktadır. Hatta bu uygarlıklarının bıraktığı eserlerin günümüzde de geçerliliğini koruduğunu görmeleri mümkün olmaktadır. Bu nedenle bir turist dünyayı tanımak amacıyla Likya Yolu'nu yürürse, genel tatmin düzeyinin artacağını söylemek mümkündür.

Likya Yolu'nu yürüyen turistler üzerinde yapılan bu araştırmada, sosyalleşme ve kendini tanıma amacıyla seyahate katılan turistlerin, yaptıkları seyahatin genel memnuniyet düzeylerini artırdığı belirlenmiştir. Likya Yolu yürüyüşü genellikle bir rehber eşliğinde yapılan seyahatlerle gerçekleştirilmektedir. $\mathrm{Bu}$ nedenle de çok sayıda insan aynı tura dahil olarak Likya Yolu'nu yürümektedirler. İnsanların bir arada olmaları bir gruba ait olmalarına ve yeni arkadaşlıklar kurmalarına firsatlar yaratmaktadır. Ayrıca Likya Yolu'nu yürüyebilmenin fiziksel bir yeterlilik gerektirmesine bağlı olarak turistler kendi yeterliliklerini görme firsatına da sahip olabilmektedirler. Bu nedenle de Likya Yolu'nu yürüme amacı sosyalleşme ve kendini gerçekleştirme olan turistlerin, gerçekleştirdikleri bu seyahatin genel memnuniyet düzeylerini artırdığ 1 söylenebilir.

Yapılan bu araştırma Likya Yolu'nu yürüyen turistlerin genel memnuniyet düzeylerinin tekrar ziyaret etme niyetleri üzerinde azaltıcı bir etkiye sahip olduğunu göstermektedir. Daha önce yapılan çalışmalarda genel memnuniyet düzeyinin tekrar ziyaret etme (Baker ve Crompton, 2000; Kozak ve Rimmington, 2000; Valle vd., 2006; Dolnicar ve Le, 2008; Okello ve Yerian, 2009; Cam, 2011; Osman ve Sentosa, 2013; Tomar ve Tomar, 2013) niyetini artırdığ belirlenmiş olmasına rağmen; turistler için oldukça zorlu etaplardan oluşan Likya Yolun'u yürüyen turistlerin, bu çalışmada tekrar Likya Yolu'nu ziyaret etme niyetinde olmadıkları belirlenmiştir. Likya Yolu'nu yürüyen turistlerin en önemli motivasyon faktörleri dünyayı tanıma ve sakinlik arayışıdır. Dünyayı tanımak amaciyla seyahat eden bir turistin ikinci defa aynı destinasyonu seyahat etmek yerine, farklı bir kültür rotasını veya destinasyonu tercih etmesi olasıdır. Bu nedenle insanların Likya Yolu'na yaptıkları seyahat sonunda genel olarak memnun olmalarına rağmen; dünyanın farklı yerlerini görmek güdüsüyle hareket ettikleri için Likya Yolu'na tekrar gelmek yerine farklı destinasyonları tercih etmek istedikleri söylenebilir.

Likya Yolu'nun tamamını yürüyebilmek için turistlerin, kişiden kişiye değişmesine rağmen ortalama olarak dört ayını ayırması gerekmektedir. Bu da her yıl 20 gün tatil yapan bir turist için neredeyse altı yıl, tatilinin tamamını bu rota üzerinde geçirmesi anlamına gelmektedir. $\mathrm{Bu}$ nedenle Likya Yolu'nu yürüyen 
turistlerin genel tatmin düzeyi yüksek olsa bile, aynı etapları uzun dönemde tekrar yürümek istememektedir (Jang ve Feng, 2007).

Genellikle yüksek düzeyde bir hizmetten memnun olan insanlar, söz konusu hizmeti etrafindaki insanlara tavsiye ederler (Finn vd., 2009; Hosany ve Prayag, 2013). Fakat bu araştırmada Likya Yolu'nu yürüyen insanların, memnuniyet düzeyleri arttıkça etrafındaki insanlara tavsiye etme niyetlerinin azaldığı belirlenmiştir. Bu beklenmeyen azaltıcı etkinin nedeni olarak, fiziksel riski fazla olan Likya Yolu'nu yürüyen insanların, etrafindaki insanların bu kültür rotasına ayıracakları zaman, çaba ve bütçe ile farklı destinasyonları görmelerinin mümkün olacağı düşünmeleri olduğunu söylemek mümkündür.

\section{Uygulayıcılara Yönelik Çıktılar}

Yapılan bu araştırmada Likya Yolu'nu yürüyen turistlerin çoğunun 46 yaş ve üzerinde, evli, 5001 tl üzerinde aylık gelire sahip, üniversite mezunu Türk vatandaşları olduğu belirlenmiştir. Turizm işletmelerinin başarılı olmalarında örgütsel kaynakların belirlenen hedef kitlenin istek ve beklentilerine uyarlanması önemlidir. Aksi durumda hizmetin yapısal özellikleri gereği önemli kayıplar ortaya çıkabilmektedir. Likya Yolu üzerinde bulunan turizm işletmesi yöneticileri pazarı demografik özelliklerine göre bölümlendirme yapmak istediklerinde pazarlama karması elamanlarını 46 yaş ve üzerindeki, 5001 tl üzerinde aylık gelire sahip, üniversite mezunu Türk vatandaşlarına göre düzenleyebilirler. Niche pazarda faaliyet göstermek isteyen turizm işletmelerinin araştırma kapsamında elde edilen diğer demografik verilerden yararlanmaları da mümkündür.

$\mathrm{Bu}$ araştırmada Likya Yolu'nu yürüyen turistleri harekete geçiren en önemli güdünün dünyayı tanıma olduğu belirlenmiştir. $\mathrm{Bu}$ nedenle Likya Yolu'nun sahip olduğu değerlerin korunması ve sürdürülebilirlik ilkesi doğrultusunda kullanılması işletmelerin uzun dönemli varlığını sürdürmeleri için gereklidir. Likya Yolu'nda bulunan işletme yöneticilerinin faaliyetleri nedeniyle ortaya çıkabilecek zararı en aza indirmeleri ve kamu kurumları tarafindan yapılacak sürdürülebilirlik çalışmalarına destek vermelerinin yararlı olacağı düşünülmektedir.

Yapılan bu araştırmada Likya Yolu'nu yürüyen turistlerin genel olarak seyahatlerinden memnun oldukları belirlenmiştir. Ancak memnun olan turistlerin Likya Yolu'nu tekrar ziyaret etmek istemedikleri ve tanıdıklarına da tavsiye etme niyetinde olmadıklarını belirlenmiştir. Bu nedenle Likya Yolu'nu yürüyerek sahip olduğu tarihi, kültürel ve doğal değerleri hakkında bilgi sahibi olan turistlerin bu yolu ikinci defa ziyaret etmek istemedikleri söylenebilir. Likya Yolu'nun başlı başına bir turist çekim gücüne sahip olsa da bölgedeki işletme yöneticileri, kamu yöneticileri ile işbirliği içerisinde bölgede ve işletmelerinde yaratacakları farkl111klarla turistlerin tekrar ziyaret etme ve tavsiye etme niyetlerini artırabilirler.

\section{Kamu Yöneticilerine Yönelik Öneriler}

Likya Yolu'nun tüm etaplarında bulunan konaklama tesislerinin sayısı ve kapasitesi hakkında resmi istatistiki bir bilgiye ulaşılamamıştır. Bu durum turizm araştırmalarını ve turizm planlamasını engellemektedir. Bu nedenle Likya 
Yolu'nu yürüyen turistlerin sayısı, Likya Yolu'ndaki turizm işletmelerinin tür, sayı ve kapasitelerini içeren istatistiklerin sağlanmasının hem uygulayıcılara hem de araştırmacılara yararlı olacağı düşünülmektedir.

Yapılan araştırma sonucunda Likya Yolu ile ilgili resmi bir web sitesine rastlanamamıştır. Likya Yolu ile ilgili web sitelerinin blog yazarları, gezginler ve rehberler tarafindan oluşturulduğu görülmüştür. Potansiyel turistlerin bilgi ihtiyacının karşılanmak için interneti kullanmaları durumunda sağlıklı bilgiye ulaşmaları zorlaşmaktadır. $\mathrm{Bu}$ nedenle kamu kuruluşlarının özel sektörün de desteğini alarak Likya Yolu'nu tanıtıcı bir web sitesi oluşturmalarının yararlı olacağ1 düşünülmektedir.

Likya Yolu boyunca 76 tane antik kent bulunmaktadır. Ancak henüz Likya Yolu, Avrupa Konseyi Kültür Rotaları arasında yer alamamıştır. Destinasyon planlamaciları Likya Yolu'nun Avrupa Konseyi Kültür Rotaları'na dahil edilmesini sağlayarak ve Konsey ile işbirliği içerisinde Likya Yolu'nun bilinirliğini arttırabilirler. Böylelikle potansiyel ziyaretçi sayısının artması mümkün olabilir.

Araştırma esnasında Likya Yolu'nda çöplerin toplanmadı̆̆ı, tabela ve levhaların yerinin değiştirildiği görülmüştür. Hijyen ve güvenlik açısından problem yaratabilecek konularda turizm işletmelerinin ve kamu yöneticilerinin daha titiz davranmaları önerilebilir.

\section{Gelecekte Yapılacak Araştırmalar İçin Öneriler}

Gelecekte yapılacak araştırmalar için öneriler getirmek mümkündür. Yapılan bu araştırmanın katılımcılarının \%65'inin Türk vatandaşı olması nedeniyle bundan sonra yapılacak araştırmalar Likya Yolu'nu yürüyen yabancı turistler örnekleminde yapılabilir. Böylelikle farklı milliyetlere sahip turistler arasında karşılaştırma imkanı olabilecektir.

$\mathrm{Bu}$ araştırmada alan araştırması Mart ve Nisan aylarında yapılmıştır. Gelecekte yapılacak araştırmalar Likya Yolu'nun bir diğer yüksek sezonu olan Eylül ve Ekim aylarında gerçekleştirilebilir. Böylelikle farklı sezonlarda Likya Yolu'nu yürüyen turistler arasında karşılaştırma imkanı olur.

$\mathrm{Bu}$ araştırma kültür rotalarından biri olan Likya Yolu üzerine yapılmıştır. Türkiye'de Kültür Rotaları Derneği kayıtlarına göre 17 adet kültür rotası bulunmaktadır. Gelecekte yapılacak araştırmalar Karia Yolu ve Idyma Yolu gibi diğer kültür rotaları üzerine tasarlanabilir. Böylelikle Türkiye'deki kültür rotalarını yürüyen turistlerin motivasyon ve tatmin düzeyleri arasında karşılaştırma yapılabilir.

\section{KAYNAKÇA}

Al-Majali, M.M. (2012). International Tourist Satisfaction. International Business Research. 5 (9): 210-216.

Alrousan, R.M. \& Abuamoud, I.M. (2013). The Mediation of Tourists Satisfaction on The Relationship Between Tourism Service Quality and Tourists Loyalty: Five Stars Hotel in Jordanian Environment. International Business Research. 6 (8): 79-90.

Baker, D.A. \& Crompton, J.L. (2000). Quality, Satisfaction and Behavioral Intentions. Annals of Tourism Research. 27 (3): 785-804. 
Bayuk, M. N. \& Küçük, F. (2007). Müşteri Tatmini ve Müşteri Sadakati İlişkisi. Marmara Üniversitesi İktisadi ve İdari Bilimler Fakültesi Dergisi. 22 (1): 285-292.

Bogoro, P., Maimako, S.S. \& Kurfi, A.F. (2013). Assessing The Role of Infrastructure on Customer Satisfaction with National Parks in North East Nigeria International Journal of Scientific and Engineering Research, 4 (10): 826-843.

Bowen, D. \& Clarke, J. (2009). Contemporary Tourist Behaviour Yourself and Others As Tourists. Oxford: Cab International.

Božić, S. \& Berić, D. (2013). Tourist Valorization of Cultural Route The Trail of The Roman Emperors. European Researcher, 55, 7 (2): 1902-1913.

Büyüköztürk, Ş. (2012). Sosyal Bilimler İçin Veri Analizi El Kitabı. Ankara: Pegem Akademi Yayıncilik.

Cam, T. (2011). Explaining Tourist Satisfaction and Intention to Revisit (Basılmamış Yüksek Lisans Tezi). Nha Trang: Nha Trang Üniversitesi Fen Bilimleri Enstitüsü.

Chen, C. \& Chen, F. (2010). Experience Quality, Perceived Value, Satisfaction and Behavioral Intentions for Heritage Tourists. Tourism Management, 31, 29-35.

Damijanić, A.T. \& Šergo, Z. (2013). Determining Travel Motivations of Wellness Tourism. İçinde D. Benic (Editör) Ekonomic Thought and Practice (ss. 3-18). Dubrovnik: Periodical of The University of Dubrovnik.

Dann, G.M.S. (1977). Anomie, Ego-Enhancement and Tourism. Annals of Tourism Research, 4 (4): 184-194.

Demir, Ş.Ş. (2010a). Çekici Faktörlerin Destinasyon Seçimine Etkisi: Dalyan Örneği. Ege Akademik Bakıs Dergisi, 10 (3): 1041-1054.

Demir, Ş.Ş. (2010b). Tatil Satın Alma Sürecinde İtici Faktörler, Bilgi Arama ve Memnuniyet İliş̧kisi: Yerli Turistler Üzerine Bir Araştırma, İşletme ve Ekonomi Araştırmaları Dergisi, 1 (4): 119-132.

Devesa, M., Laguna, M. \& Palacios, A. (2010). The Role of Motivation in Visitor Satisfaction: Empirical Evidence in Rural Tourism. Tourism Management. 31, 547-552.

Dolnicar, S. \& Le, H. (2008). Segmenting Tourists Based on Satisfaction and Satisfaction Patterns. İçinde A. Yüksel (Editör) Tourist Satisfaction and Complaining Behaviour: Measurement and Management Issues in The Tourism and Hospitality Industry (ss. 186-204). New York: Nova Science Publishing.

Duman, T. \& Öztürk, A.B. (2005). Yerli Turistlerin Mersin Kızkalesi Destinasyonu ve Tekrar Ziyaret Niyetleri ile İlgili Algılamaları Üzerine Bir Araştırma. Anatolia: Turizm Araştırmaları Dergisi, 16 (1): 9-23.

Ekiz, E.H. \& Köker, N.E. (2012). Destinasyon Tatmininin Belirleyicileri: Kuzey Kıbrıs Türk Cumhuriyeti'ni Ziyaret Eden Yabancı Turistlerin Algılamaları. Küresel İletişim Dergisi, 2 (4): 45-63.

Evren, S. \& Kozak, N. (2012). Eskişehir'in Çekici Faktörlerinin Günübirlik Ziyaretçilerin Bakış Açılarıyla Değerlendirilmesi, Anatolia: Turizm Araştırmaları Dergisi, 23 (2): 220-232.

Finn, A., Wang, L. \& Frank, T. (2007). Attribute perceptions, customer satisfaction and intention to recommend e-services. Journal of Interactive Marketing, 23, 209-220.

Francis, C. (2003). Tourism overview. İçinde B. Lubbe (Editör) Tourism Management in Southern Africa (ss.29-69). Cape Town: Maskew Miller Longman.

Hair, J.F., Black, B., Babin, B., Anderson, R.E. \& Tatham, R. L. (2009). Multivariate Data Analysis. New York: Pearson Prentice Hall.

Harman, S. (2012). Sırtçantalı Turistlerin Seyahat Motivasyonları ve İlgilenimleri: İstanbul'a Gelen Sırtçantalı Turistler Üzerinde Bir Araştırma. (Basılmamış Doktora Tezi) Çanakkale: Onsekiz Mart Üniversitesi Sosyal Bilimler Enstitüsü.

Heitmann, S. (2010). Tourist Behaviour and Tourism Motivation. İçinde P. Robinson, S. Heitmann ve P. Dieke (Editörler), Research Themes for Tourism (ss. 31-44). Oxford: Cab International.

Hosany, S. \& Prayag, G. (2011). Patterns of Tourists' Emotional Responses, Satisfaction, and Intention to Recommend. Journal of Business Research. 30, 1-7. 
Hosany, S. \& Prayag, G. (2013). Patterns of tourists' emotional responses, satisfaction, and intention to recommend. Journal of Business Research, 66, 730-737.

Hsu, C.H.C. \& Huang, S. (2008). Travel Motivation: A Critical Review of The Concept's Development. İçinde A. Woodside ve D. Martin (Editörler), Tourism Management Analysis, Behaviour and Strategy (ss.14-27). Oxford: Cab International.

Huh, J. (2002). Tourist Satisfaction with Cultural/Heritage Sites: The Virginia Historic Triangle. (Basılmamış Yüksek Lisans Tezi) Virginia: State Üniversitesi Virginia Politeknik Enstitüsü.

Hummelbrunner, R. \& Miglbauer, E. (1994). Tourism promotion and potential in Peripheral Areas: The Austrian case. Journal of Sustainable Tourism, 2, 41-50.

Jang, S. \& Wu, C.E. (2006). Seniors' Travel Motivation and The Influential Factors: An Examination of Taiwanese Seniors. Tourism Management. 27, 306-316.

Jang, S.S. \& Feng, R. (2007). Temporal destination revisit intention: The effects of novelty seeking and satisfaction, Tourism Management 28, 580-590.

Jones, T.O. \& Sasser, W.E. (1995). Why Satisfied Customers Defect. Harvard Business Review, $6838,1-14$.

Jönsson, C. \& Devonish, D. (2008). Does Nationality, Gender and Age Affect Travel Motivation: A Case of Visitors to The Caribbean Island of Barbados. Journal of Travel and Tourism Marketing. 25 (3-4): 398-408.

Kasim, A., Dzakiria, H., Park, C., Azila, N., Nor, M. \& Mokhtar, F.M. vd. (2013). Predictors of Travel Motivations: The Case of Domestic Tourists to Island Destinations in Northwest of Malaysia. Anatolia: An International Journal of Tourism Research, 24 (2): 188-205.

Klenosky, D.B. (2002). The Pull of Tourism Destinations: A Mean-end Investigation. Journal of Travel Research, 40 (4): 385-395.

Kotler, P., Armstrong, G., Wong, V. \& Saunders, T. (2008). Principles of marketing. Harlow: Pearson Education.

Kozak, M. (2002). Comparative Analysis of Tourist Motivations by Nationality and Destinations. Tourism Management, 23, 221-232.

Kozak, M. \& Rimmington, M. (2000). Tourist Satisfaction with Mallorca, Spain as An Off-Season Holiday Destination. Journal of Travel Research, 38, 260-269.

Latu, T.M. \& Everett, A.M. (2000). Review of Satisfaction Research and Measurement Approaches (Tech. Rep. No. 183). Dunedin, New Zealand: University of Otago, Department of Management.

Ma, B. (2010). A Trip Into the Controversy: A Study of Slum Tourism Travel Motivations. İçinde P. Conn (Chair), Undergraduate Humanities Forum Research. University of Pennsylvania Humanities Forum, Pennsylvania, United States of America.

McIntosh, R.W., Goeldner, C.R. \& Ritchie, J.R.B. (1995). Tourism Principles, Practices, Philosophies. New York: Wiley.

Meng, F., Tepanon, Y. \& Uysal M. (2008). Measuring Tourist Satisfaction by Attribute and Motivation: The Case of Nature-Based Resort. Journal of Vacation Marketing, 14 (1): 41 55.

Meyer, D. (2004). Tourism Routes and Gateways: Key Issues for The Development of Tourism Routes and Gateways and Their Potential for Pro-poor Tourism. Sheffield Hallam Üniversitesi, Deniz Aşırı Kalkınma Enstitüsü’nden 10 Mayıs 2014 tarihinde www.odi.org.uk/resources/docs/4040.pdf internet sitesinden edinilmiştir.

Mlozi, S. \& Pesamaa, O. (2013). Adventure Tourist Destination Choice in Tanzania. Current Issues in Tourism, 16 (1): 63-95.

Mohammad, B.A.A. \& Som, A.P.M. (2010). An Analysis of Push and Pull Travel Motivations of Foreign Tourists to Jordan. International Journal of Business and Management, 5 (12): 4150 .

Musai, M., Mahrera, M. \& Arkadani, H.M. (2013). Motivational factors of travel to war places in Iran. International Journal of Academic Research in Business and Social Sciences, 3 (1): 314-323. 
Okello, M.M. \& Yerian, S. (2009). Tourist Satisfaction in Relation to Attractions and Implications for Conservation in The Protected Areas of The Northern Circuit, Tanzania. Journal of Sustainable Tourism, 17 (5): 605-625.

O'Leary, S. \& Deegan J. (2003). People, Pace, Place: Qualitative and Quantitative Images of Ireland as a Tourism Destination in France. Journal of Vacation Marketing, 9 (3): 213-226.

Osman, Z. \& Sentosa, M. (2013). Mediating Effect of Customer Satisfaction on Service Quality and Customer Loyalty Relationship in Malaysian Rural Tourism. International Journal of Economics Business and Management Studies, 2 (1): 25-37.

Paris, C.M. \& Teye, V. (2010). Backpacker Motivations: a Travel Career Approach. Journal of Hospitality Marketing and Management, 19 (3): 244-259.

Pearce, P. (1988) The Ulysses Factor: Evaluating Visitors in Tourist Settings. New York: Springer Verlag.

Pearce, P.L. \& Caltabiano, M. (1983). Inferring Travel Motivations from Travelers' Experiences. Journal of Travel Research, 22 (2): 16-20.

Pearce, P.L. \& Lee, U. (2005). Developing The Travel Career Approach to Tourist Motivation. Journal of Travel Research, 43 (3): 226-237.

Pesonen, J.A. (2012). Segmentation of Rural Tourists: Combining Pull and Push Motivations. Tourism and Hospitality Management, 18 (1): 69-82.

Prayag, G. (2008). Image, Satisfaction and Loyalty The Case of Cape Town. Anatolia: An International Journal of Tourism and Hospitality Research, 19 (2): 205-224.

Prayag, G. (2009). Tourists' Evaluations of Destination Image, Satisfaction and Future Behavioral Intentions The Case of Mauritius. Journal of Travel and Tourism Marketing, 26, 836-853.

Prebensen, N. (2003). Tourist Satisfaction with a Destination: Antecedents and Consequences. Finnmark College Konaklama İşletmeciliği Departmanından (10 Mart 2014) tarihinde http://www.esade.edu/cedit2004/pdfs/52_Prebensen.pdf internet adresinden edinilmiştir.

Sadeh, E., Asgari, F., Mousavi, L. \& Sadeh, S. (2012). Factors Affecting Tourist Satisfaction and Its Consequences. Journal of Basic and Applied Scientific Research, 2 (2): 1557-1560.

Sangkaworn, C. \& Mujtaba, B. G. (2010). Marketing Practices of Hotels and Resorts in Chiang Mai: A Study of Products, Pricing, and Promotional practices. Journal of Management and Marketing Research, 4(1): 165-183

Song, H., Veen, R., Li, G. \& Chen, J.L. (2011). The Hong Kong Tourist Satisfaction Index. Annals of Tourism Research, 39 (1): 459-479.

Swarbrooke, J. \& Horner, S. (2007). Consumer Behaviour in Tourism. Oxford: Elsevier.

Terblanche, H. (2012). Travel Motives of Adventure Tourists: A Case Study of Mageobaskloof Adventures. (Basılmamış Yüksek Lisans Tezi) Potchefstroom: North-West Üniversitesi.

Tidtichumrernporn, T., Janasak, S., Mujtaba, B.G., Khunsongkiet, P., Duangjai, N. \& Bhawanantechanon, N. (2010). Measuring the Satisfaction of Domestic and International Tourists toward Lanna Cultural Tourism Products: A Study of Progress in Chiang Mai Walking Street Activities. Journal of Business Studies Quarterly, 1 (3): 31-52.

Tomar, R.S. \& Tomar, D.S. (2013). Measuring Foreign Traveler's Satisfaction with Traveling Agencies in India. Journal of Business and Management, 12 (1): 26-32.

Turgut, İ. \& Clow, K. (2010). Likya Yolu'nda Yürümek. İstanbul: Mart Matbaac1lık.

Ural, A. \& Kılıç, İ. (2006). Bilimsel Araştırma Süreci ve SPSS ile Veri Analizi. Ankara: Detay Yayıncilik.

Valle, P., Silva, J.A., Mendes, J. \& Guerreiro, M. (2006). Tourist Satisfaction and Destination Loyalty Intention: A Structural and Categorical Analysis. International Journal of Business Science and Applied Management, 1 (1): 25-44.

Weiler, B. \& Ham, S. (2004). Relationship Between Tourist and Trip Characteristics and Visitor Satisfaction: A Case Study of The Panama Canal Watershed. Monash University Business and Economics, 59 (4): 1-11.

Yoon, Y. \& Uysal, M. (2005). An Examination of The Effects of Motivation and Satisfaction on Destination Loyalty: A Structural Model. Management Tourism, 26, 45-56.

Yüksel, A.\& Yüksel, F. (2008). Different Nationalities, Different Holiday, Motivations and Attribute-Seeking Patterns. İçinde A. Yüksel (Editör) Tourist Satisfaction and Complaining 
Behavior: Measurement and Management Issues in The Tourism and Hospitality Industry (ss.167-185). New York: Nova Science Publishers.

\section{SUMMARY}

Lycian Way which is 23 stages and $509 \mathrm{~km}$ length is visited by thousands of tourists each year because of its natural and cultural beauty. In this research, it is aimed to determine demographical characteristics, travel motivations, general satisfaction levels and intention to revisit of tourists walking Lycian Way. In this context, Travel Motivations Scale, a questionnaire form consisting of multiple choice items and demographic questions to determine the satisfaction level of tourists and destination loyalty, has been prepared in Turkish and English. This questionnaire has been applied face to face with the tourists in Hisarönü, Faralya, Kaş, Mavikent, Gelidonya Feneri and Adrasan Stages of Lycian Way in March and April of 2014 with convenience sampling method. At the end of the data collection process, a total of 407 available surveys were obtained. 31 years old or above that age; nearly half of them have associate degrees and undergraduate academic degrees; most of them are from Turkey and Germany. The validity and reliability of the Travel Motivations Scale were determined by exploratory and confirmatory factor analysis. It has been determined in the study that the travel motivations of the tourists walking The Lycian Way can be examined under the titles such as socializing and self-realization, traveling independently, knowing the world, searching for experience and quietness.

The scope of the research proposed to test the hypothesis, correlation and regression analyses were conducted. A meaningful relation between the item knowing the world and general satisfaction level has been determined at correlation analysis. It has also been determined that socializing and selfrealization motivation affect the general satisfaction level meaningful. It has been observed that the general satisfaction level has a negative effect on the intention of revisiting the same place and on the intention of recommending it to other people. Based on the results of the research, it has been empirically proven that level of overall satisfaction with walking tourists who self-realization with basic travel motivation have a high in the Lycian Way. However, it is possible to say that tourists walking on the Lycian Way do not intend to revisit and recommend it to others, although their satisfaction level is generally high. Theoretically, it is accepted that there is a significant positive relationship between satisfaction, revisit and recommendation. It is believed that the main reason why this empirical research does not support the theory is that the Lycian Way is composed of many stages and physical difficulties in walking these stages. In order to be able to walk the entire Lycian Way, the next stage may be preferred by the tourists to continue the next stage by not walking the same step a second time or a different stage. 